Research

\title{
Malaria transmission in Dakar: A two-year survey
} Frederic Pagès*1, Gaetan Texier1, Bruno Pradines², Libasse Gadiaga ${ }^{3}$, Vanessa Machault ${ }^{1}$, Fanny Jarjaval ${ }^{1}$, Kristell Penhoat ${ }^{2}$, Franck Berger ${ }^{4}$, JeanFrançois Trape ${ }^{3}$, Christophe Rogier ${ }^{2}$ and Cheikh Sokhna ${ }^{3}$

\begin{abstract}
Address: ${ }^{1}$ Unité d'Entomologie Médicale - Unité de Recherche pour les Maladies Infectieuses et Tropicales Emergentes - Unité Mixte de Recherche 6236, Institut de Médecine Tropicale du Service de Santé des Armées, Bd Charles Livon, Parc du Pharo, 13998 Marseille, France, ${ }^{2}$ Unité de Recherche en Biologie et Epidémiologie Parasitaires - Unité de Recherche pour les Maladies Infectieuses et Tropicales Emergentes - Unité Mixte de Recherche 6236, Institut de Médecine Tropicale du Service de Santé des Armées, Marseille, France, ${ }^{3}$ Institut de Recherche pour le Développement, Dakar, Sénégal and "Département d'Epidémiologie et de Santé Publique Nord, Ecole du Val-de-Grâce, Paris, France

Email: Frederic Pagès* - frederic_pages@yahoo.com; Gaetan Texier - gaetex1@gmail.com; Bruno Pradines - bruno.pradines@free.fr; Libasse Gadiaga - gadiagalibass@yahoo.fr; Vanessa Machault - vanessamachault@yahoo.com.br; Fanny Jarjaval - fanny.jarjaval@wanadoo.fr; Kristell Penhoat - imtssa.parasito@wanadoo.fr; Franck Berger - desp.valecole@wanadoo.fr; Jean-François Trape - trape@ird.sn; Christophe Rogier - christophe.rogier@wanadoo.fr; Cheikh Sokhna - cheikh.sokhna@ird.sn

* Corresponding author
\end{abstract}

Published: 16 September 2008

Malaria Journal 2008, 7:178 doi:10.1 186/1475-2875-7-178
Received: II June 2008

Accepted: 16 September 2008

This article is available from: http://www.malariajournal.com/content/7/I/178

(C) 2008 Pagès et al; licensee BioMed Central Ltd.

This is an Open Access article distributed under the terms of the Creative Commons Attribution License (http://creativecommons.org/licenses/by/2.0), which permits unrestricted use, distribution, and reproduction in any medium, provided the original work is properly cited.

\begin{abstract}
Background: According to entomological studies conducted over the past 30 years, there was low malaria transmission in suburb of Dakar but little evidence of it in the downtown area. However; there was some evidence of local transmission based on reports of malaria among permanent residents. An entomological evaluation of malaria transmission was conducted from May 2005 to October 2006 in two areas of Dakar.

Methods: Mosquitoes were sampled by human landing collection during 34 nights in seven places in Bel-air area (238 person-nights) and during 24 nights in five places in Ouakam area (I 20 person-nights). Mosquitoes were identified morphologically and by molecular methods. The Plasmodium falciparum circumsporozoïte indexes were measured by ELISA, and the entomological inoculation rates (EIR) were calculated for both areas. Molecular assessments of pyrethroid knock down resistance $(K d r)$ and of insensitive acetylcholinesterase resistance were conducted.

Results: From May 2005 to October 2006, 4,II7 and 797 Anopheles gambiae s.l. respectively were caught in Belair and Ouakam. Three members of the complex were present: Anopheles arabiensis (>98\%), Anopheles melas (< $1 \%)$ and An. gambiae s.s. molecular form $M(<1 \%)$. Infected mosquitoes were caught only during the wintering period between September and November in both places. In 2005 and 2006, annual EIRs were 9,5 and 4, respectively, in Bel-air and 3 and 3, respectively, in Ouakam. The proportion of host-seeking An. gambiae s.l. captured indoors were $17 \%$ and $51 \%$ in Bel air and Ouakam, respectively. Ace I mutations were not identified in both members of the An. gambiae complex. Kdr mutation frequency in An. arabiensis was I2\% in Bel-air and $9 \%$ in Ouakam.

Conclusion: Malaria is transmitted in Dakar downtown area. Infected mosquitoes were caught in two subsequent years during the wintering period in two distant quarters of Dakar. These data agree with clinical data from a Senegalese military Hospital of Dakar (Hospital Principal) where most malaria cases occurred between October and December. It was the first detection of An. melas in Dakar.
\end{abstract}




\section{Background}

In the sixties, the relative seriousness of malaria and the seasonal transmission of Plasmodium falciparum by Anopheles gambiae s.l. in Dakar were reported in different studies [1-4]. Immunity was acquired quite slowly during the first 20 years of life [5]. Malaria-infected individuals came from rural areas to Dakar and contributed to the start of transmission, which culminated in October-November after the end of the rainy period [6]. In the eighties, an entomological survey proved that malaria transmission occurred in Pikine in the suburb of Dakar and that Anopheles arabiensis was the main vector in this area [6]. In the nineties, malaria transmission persisted in Pikine and in the surrounding villages of Dakar, always with An. arabiensis as the vector [7]. During the same period, two parasitological and entomological studies conducted in two sanitary districts of Dakar showed that the prevalence of malaria was very low; a few An. arabiensis were caught, and none of them were infected by $P$. falciparum [8-10]. Based on these results, many practitioners thought that there was no malaria transmission in Dakar intra-muros (i.e. in the down-town area) and that the infections occurred in the suburbs or inland. Nevertheless, human malaria cases were reported in autochthonous people who had not been outside Dakar for at least one year, suggesting that malaria was transmitted in Dakar [10]. At the same time, French military doctors were confronted with malaria cases in expatriates, who were visiting a malaria endemic country for the first time, but had never left downtown Dakar. To assess the reality of malaria transmission in Dakar, an entomological evaluation was conducted at the French military bases of Dakar from May 2005 to October 2006, over two winters.

\section{Materials and methods Location}

Located at $14^{\circ} 40^{\prime} 20^{\prime \prime}$ North, $17^{\circ} 25^{\prime} 22^{\prime \prime}$ West (the westernmost point of Africa), Dakar, the capital city of Senegal, has 1,030,594 inhabitants and covers the major part of the Cap Vert Peninsula. The altitude does not exceed $104 \mathrm{~m}$. The population of the Dakar area is estimated to be 2.45 million people, representing $20 \%$ of the Senegalese population. The estimated population density is 12,233 inhabitants/ $\mathrm{km}^{2}$.

The study was conducted in two districts of Dakar: Bel-air in the east of the city and Ouakam in the west (Figure 1). Bel-air is a residential district with luxuriant vegetation and with many market gardens and water wells along a railway, which crosses the area. The French military camp is bordered by the sea on three sides and by the railway on the other side. Ouakam is also a residential district with individual and collective houses. The French military camp of Ouakam is bordered by the sea on the west side and by houses on the other sides. It is a dry area with little vegetation. Between the camp and the sea lie a market gardens area and two water wells. The waste water of the French camp flows into a network that irrigates all the market gardens.

\section{Climate}

The Cap Vert Peninsula is located in the Atlantic Sudan zone. Two distinct seasons exist: a hot and wet season from June to November (maximum average temperature $28.2^{\circ} \mathrm{C}$ in October) and a cool and dry season from December to May (minimum average temperature $20.4^{\circ} \mathrm{C}$ in February). The first rains generally occur at the end of June or the beginning of July, and the last occur at the beginning of October. In 2005 and 2006 (the period covered by the study), the average rainfall was 525 and $350 \mathrm{~mm}$, respectively.

\section{Field mosquito processing}

Sampling by human landing of malaria vectors was carried out both indoors and outdoors. Collectors gave prior informed consent and received anti-malaria prophylaxis and yellow fever immunization. Collectors were organized in teams of two for each collection point. Replacement of workers within a team was done every two hours from 7:00 PM to 7:00 AM. Teams of collectors were rotated among the collection points on different collection nights to minimize sampling bias. Landing catches were performed at seven points (two places indoors and five outdoors) in two periods, from May 2005 to May 2006 and from September to October 2006, during 34 nights in Bel-air (i.e. 238 person-nights). In Ouakam, human landing collections were performed at five points (two indoor and three outdoor locations) for two periods, from July 2005 to May 2006 and from September to October 2006, during 24 nights (i.e. 120 person-nights).

Mosquitoes were recorded by the location and hours of capture. They were sorted by genera, and anopheline mosquitoes were identified morphologically following the Gillies and Coetzee keys and by software from Hervy et al $[11,12]$. Culicinae were identified morphologically following the Edwards keys [13]. All mosquitoes were stored individually in numbered vials with desiccant and preserved at $-20^{\circ} \mathrm{C}$ until processing at the Medical Entomology Unit of the Institute for Tropical Medicine (IMTSSA), Marseille (France).

\section{Laboratory mosquito processing}

Heads and thoraces of anopheline females were tested by enzyme-linked immunosorbent assay (ELISA) for P. falciparum circumsporozoite protein (CSP)[14]. All females belonging to the A. gambiae complex caught during the dry season, a random sample of females caught during the rainy season, together with all CSP-positive anopheline, were identified by polymerase chain reaction (PCR) at the 


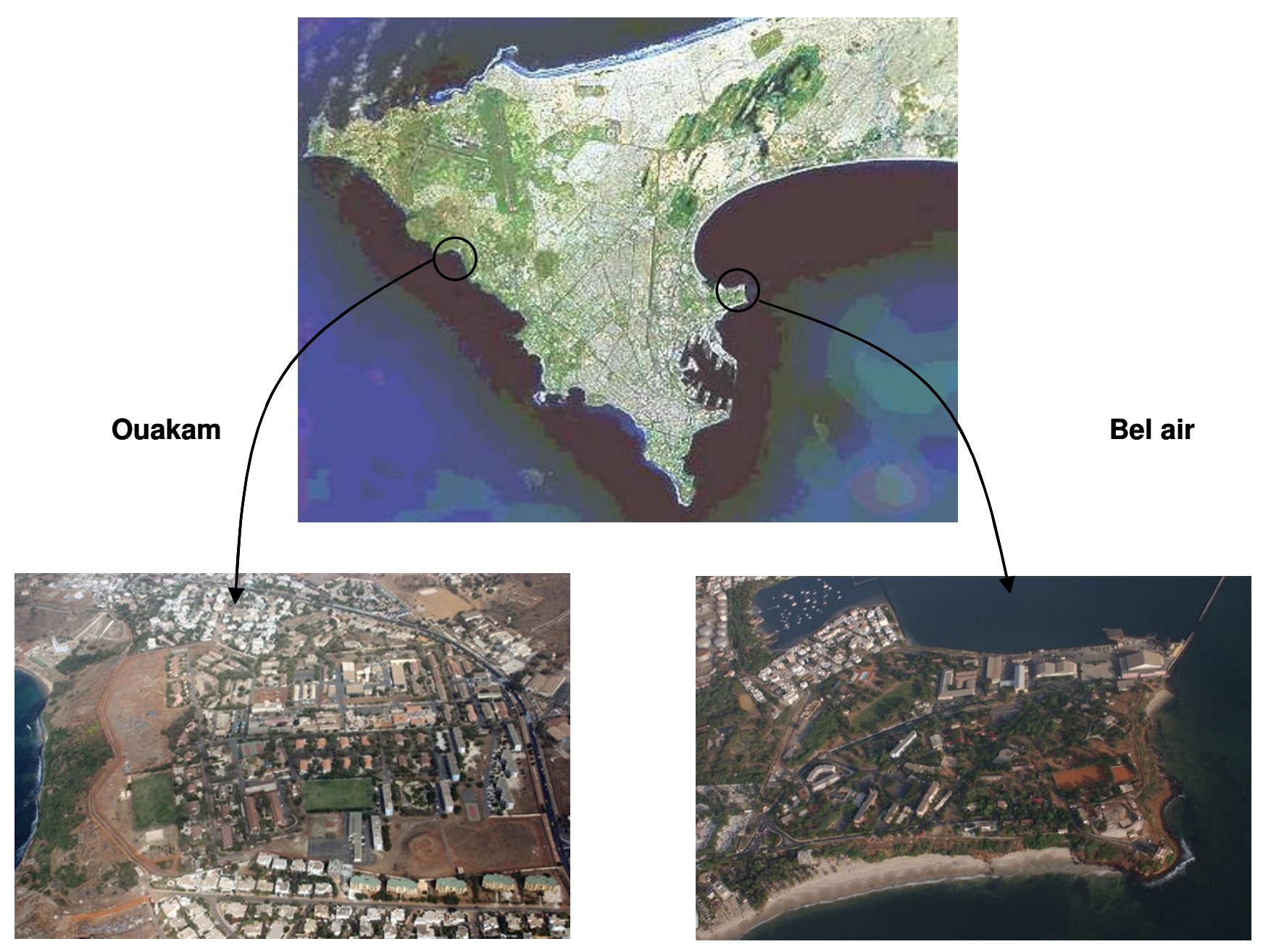

Figure I

Localization and surroundings of the French military camps in Dakar.

species and molecular forms levels [15]. Molecular characterizations of the $K d r$ and Ace1 mutations were carried out on these mosquitoes as previously described [16,17].

\section{Data analysis}

The human biting rate (HBR) was expressed as the number of female anopheline bites per human per night. The CSP index was calculated as the proportion of mosquitoes found to be positive for CSP. The entomological inoculation rate (EIR) was calculated as the product of the HBR and the CSP index of mosquitoes collected on humans. The An. gambiae s.l. biting activity is sufficient for transmission only during the end of the rainy period; the EIR calculated for this period will be considered as the annual EIR. Conformity of $K d r$ and Ace 1 frequencies with Hardy-Weinberg expectations was tested using a Pearson chi-square test considered significant when $\mathrm{P}<0.05$. Endophagic rates were compared using a chi-square test.

\section{Weather data}

Rainfall data were graciously provided by the National Weather Agency.

\section{Results \\ Mosquito collection}

A total of 69,082 mosquitoes were caught $(76.4 \%$ Culex quinquefasciatus, 13.9\% Culex tritaeniorynchus, 7.1\% An. gambiae s.l., 2.2\% Aedes aegypti; Tables 1 and 2).

\section{Biting rates and biting behaviour of An. gambiae s.I}

The biting activity at the two sites from May 2005 to May 2006 is shown in Figure 2. An. gambiae s.l. was present throughout the year in Dakar, but most of the specimens (98\%) were caught between July and December. The peak of biting occurred in September and October, at the end of the winter period (rainy season): $67 \%$ and $87 \%$ of mosquitoes were caught during these two months in Ouakam 
Table I: Mosquitoes collected in the French military camps of Dakar from May 2005 to May 2006: distribution by species, camps, periods and place of capture (indoor or outdoor).

\begin{tabular}{|c|c|c|c|c|c|}
\hline & \multicolumn{4}{|c|}{ From May 2005 to May 2006} & \multirow{3}{*}{ TOTAL } \\
\hline & \multicolumn{2}{|c|}{ Bel-air } & \multicolumn{2}{|c|}{ Ouakam } & \\
\hline & Indoor & Outdoor & Indoor & Outdoor & \\
\hline Anopheles gambiae s.l. & 346 & 2703 & 242 & 347 & 3638 \\
\hline Anopheles pharoensis & 2 & 17 & 0 & 1 & 20 \\
\hline C. quinquefasciatus & 12024 & 26407 & 1480 & 3568 & 43479 \\
\hline C. tritaeniorynchus & 419 & 5230 & 71 & 1585 & 7305 \\
\hline Aedes aegypti & 113 & 964 & 26 & 256 & 1359 \\
\hline Aedes metallicus & 2 & 81 & 4 & 82 & 169 \\
\hline Aedes vitattus & & 7 & & & 7 \\
\hline Mansonia sp & & 4 & & & 4 \\
\hline Aedeomyia sp & & & & 2 & 2 \\
\hline
\end{tabular}

and Bel-air, respectively. During this period in 2005, in Bel-air, the average biting rate for An. gambiae s.l. was 112 bites per person per night, with a peak of 181 bites per person per night; in Ouakam, the average biting rate for An. gambiae s.l. was 19.7 bites per person per night, with a peak of 37.2 bites per person per night. During September-October in 2006, the average rates in Bel-air and Ouakam were 19.1 and 10.4 An. gambiae s.l. bites per person per night, respectively. The distribution of An. gambiae s.l. bites by hour is shown in Figure 3. Indoors over $70 \%$ of biting occurred between 1:00 a.m. and 6:00 a.m. in Ouakam and between 2:00 a.m. and 7:00 a.m. in Bel-air; outdoors, over 70\% of biting occurred between 1:00 a.m. and 6:00 a.m. in both locations.

The average number per catching point of host-seeking An. gambiae s.l. caught indoor and outdoor were 121 and 115, respectively in Ouakam and 115 and 540, respectively in Bel air. The proportion of host-seeking An. gambiae s.l. captured indoors were $51 \%$ and $17 \%$ in Ouakam and Bel air, respectively. $(\mathrm{P}<0.0001, \mathrm{RR}=2.92[2.37$;
3.59], indicating that this species was more endophagic in Ouakam.

\section{CSP and EIR}

In Bel-air, 3,049 An. gambiae s.l. collected by human landing catches were processed by ELISA for $P$. falciparum antigen detection in 2005, and 1,084 were processed in 2006. Assuming that malaria transmission could occurred only in the end of the rainy season, CSP index has been calculated only from the end of September to December. From May 2005 to the middle of September 2005, none of the 1,546 mosquitoes were positive for CSP. From the end of September to December, seven specimens among 1,503 were CSP positive. The CSP index was $0.46 \%$ (CI95\% = 0.19-0.96). From December 2005 to May 2006, none of the 16 mosquitoes were positive for CSP. In September and October 2006, three specimens among 1,068 were positive. The CSP index was $0.28 \%$ (CI95\% $=0.06-0.82$ ).

Infected mosquitoes were identified only between the end of the rainy season. In 2005 and 2006, annual EIRs were

Table 2: Mosquitoes collected in the French military camps of Dakar from September to October 2006: distribution by species, camps, periods and place of capture (indoor or outdoor).

\begin{tabular}{|c|c|c|c|c|c|}
\hline & \multicolumn{4}{|c|}{ From September to October 2006} & \multirow{3}{*}{ TOTAL } \\
\hline & \multicolumn{2}{|c|}{ Bel-air } & \multicolumn{2}{|c|}{ Ouakam } & \\
\hline & Indoor & Outdoor & Indoor & Outdoor & \\
\hline Anopheles gambiae s.l. & 78 & 990 & 23 & 185 & 1276 \\
\hline Anopheles pharoensis & 2 & 4 & & & 6 \\
\hline C. quinquefasciatus & 858 & 7713 & 252 & 475 & 9298 \\
\hline C. tritaeniorynchus & 43 & 2100 & 3 & 159 & 2305 \\
\hline Aedes aegypti & 2 & 156 & 8 & 34 & 200 \\
\hline Aedes metallicus & & & & & 0 \\
\hline Aedes vitattus & & 3 & & & 3 \\
\hline Mansonia sp & & II & & & II \\
\hline Aedeomyia sp & & 0 & & & 0 \\
\hline
\end{tabular}


Malaria Journal 2008, 7:178

http://www.malariajournal.com/content/7/1/178
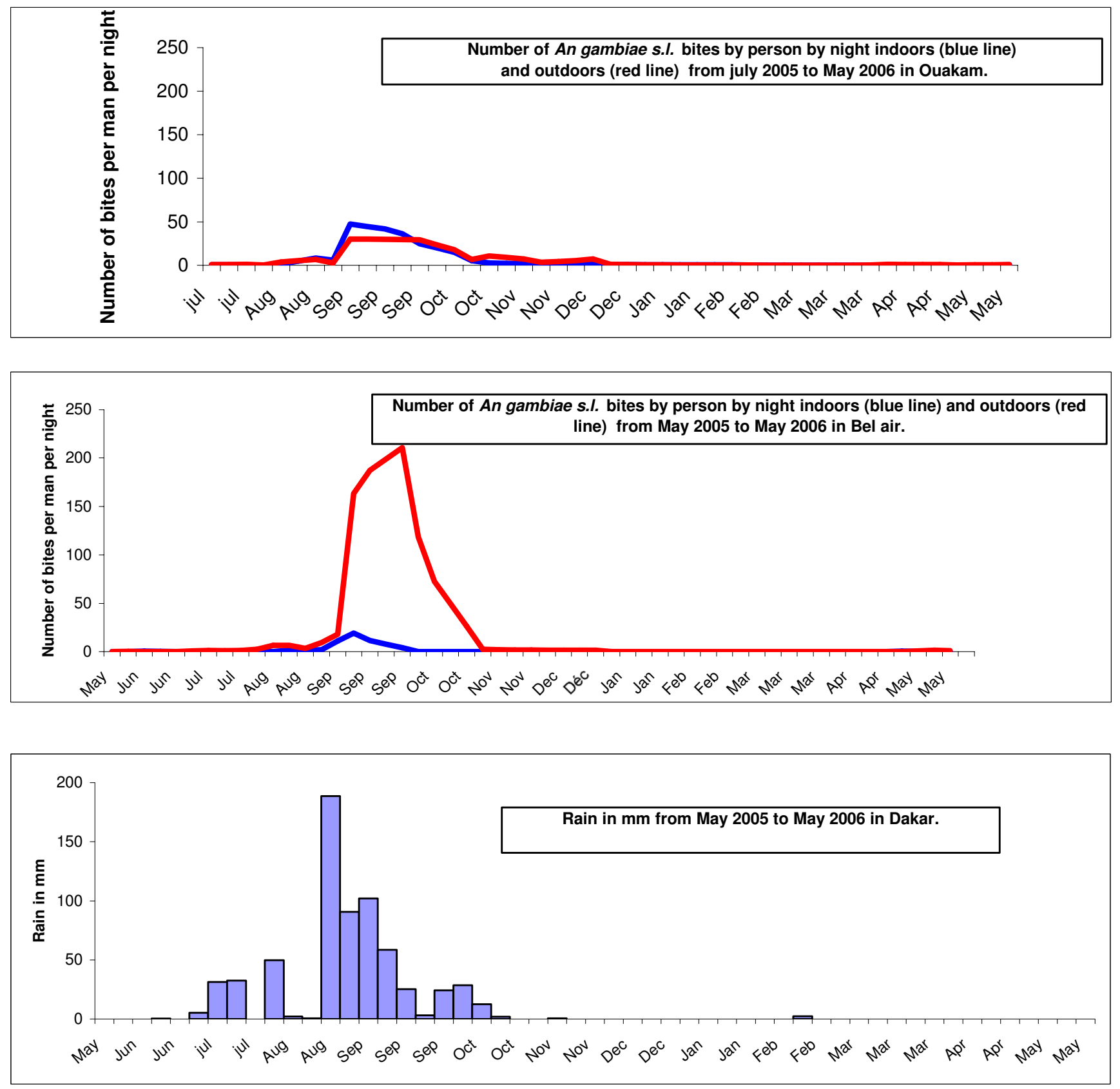

Figure 2

Outdoor and indoor aggressiveness of An. gambiae s.l. in Ouakam and Bel air from May 2005 to May 2006 , and rainfall.

9.5 and 4 infective bites for a person without protection, respectively.

In Ouakam, 589 An. gambia s.l. collected by human landing catch were processed by ELISA for $P$. falciparum antigen detection in 2005, and 217 were processed in 2006. From July to the middle of September 2005, none of the
279 mosquitoes were positive. From the end of September to December, two specimens among 310 were positive. The CSP index was $0.64 \%(\mathrm{CI} 95 \%=0.08-2.30)$. From December 2005 to May 2006, none of the 9 mosquitoes were positive. In September and October 2006, two specimens among 1,068 were positive. The CSP index was $0.96 \%(\mathrm{CI} 95 \%=0.12-3.40)$. In 2005 and 2006, annual

Page 5 of 11

(page number not for citation purposes) 

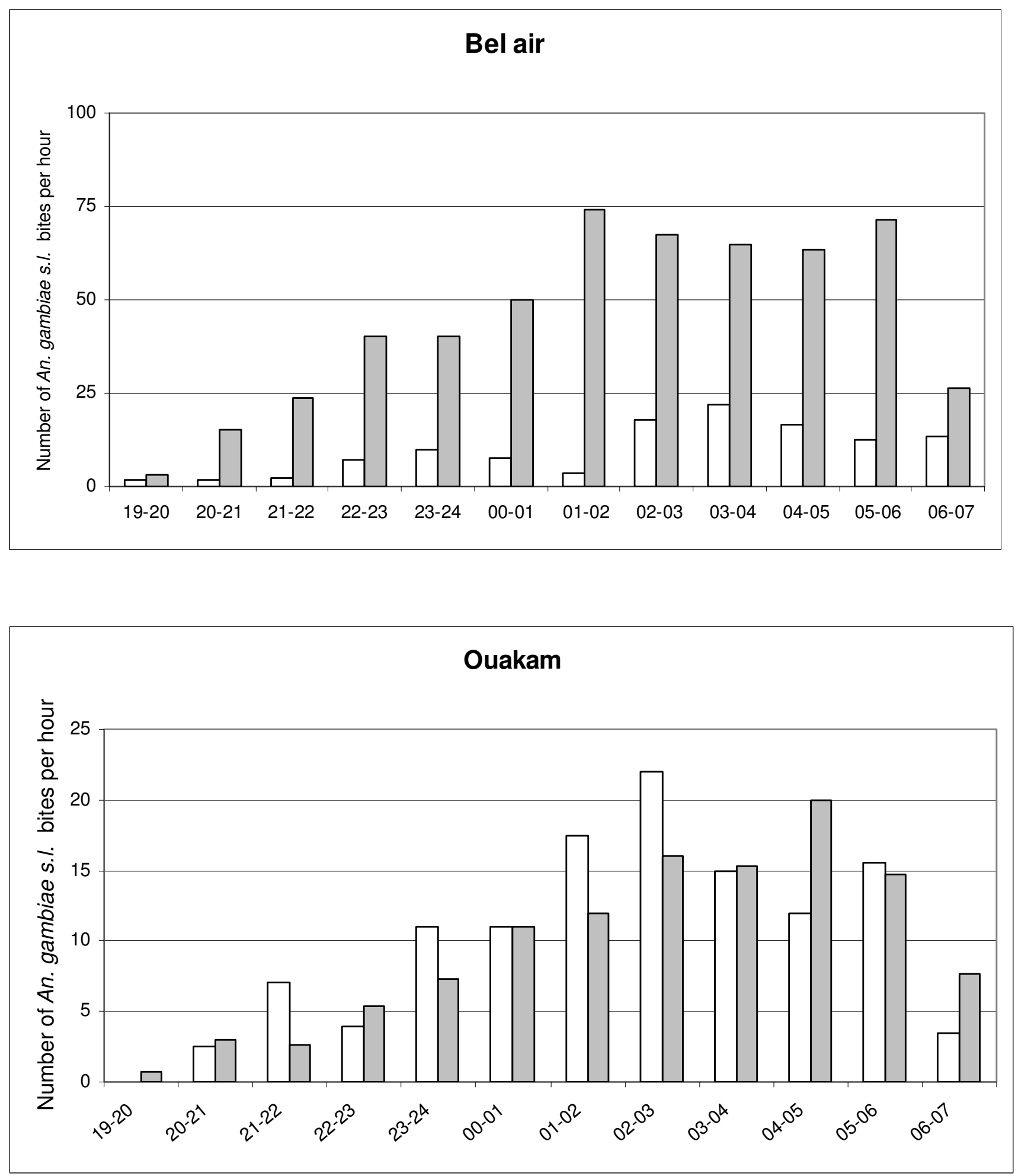

Figure 3

Distribution by hours of An. gambiae s.l. bites indoors (white bars) and outdoors (gray bars) in Dakar, May 2005 to May 2006. 
EIRs were 3 and 3 infective bites for a person without protection, respectively.

\section{Molecular identification of An. gambiae s.I}

Using rDNA-PCR, all specimens of An. gambiae s.l. captured before September 2005 (373 from Bel-air, and 82 from Ouakam), a random sample of the mosquitoes caught from September to December 2005 (346 from Belair and 216 from Ouakam), a random sample of the mosquitoes caught in September and October 2006 (137 from Bel-air and 134 from Ouakam), and all CSP-positive specimens were identified at the species level. In Bel-air, three members of the complex were present in 2005: An. arabiensis (97.8\%), Anopheles melas (2.0\%) and An. gambiae s.s. molecular form M (0.2\%). In 2006, only An. arabiensis (98.5\%) and An. gambiae s.s. molecular form M (1.5\%) were present. In Ouakam, and only An. arabiensis was present in 2005. In 2006, one specimen of An. melas was caught. Emerging adults and all CSP-positive specimens were An. arabiensis.

Kdr-w and Acel mutation frequencies in An. gambiae s.I All CSP-positive mosquitoes per site and a random sample of 100 PCR-identified mosquitoes were tested for the $K d$-wr and Ace 1 mutations. Ace 1 mutations were not identified in any members of the An. gambiae complex either in Ouakam or in Bel-air. The Kdr-w mutation frequency in An. arabiensis was $12 \%$ in Bel-air and $9 \%$ in Ouakam (not a significant statistical difference). The genotypic frequencies are shown in Table 3 . The populations were not at Hardy-Weinberg equilibrium at either site for $\operatorname{kdr}(\mathrm{P}<0.0001)$.

\section{Discussion}

Malaria transmission is a reality in Dakar. P. falciparuminfected Anopheles have been caught during two rainy periods consecutively in two quarters of the town. All infected An. gambiae s.l. were caught only during the rainy period. The seasonal transmission occurs in the end of the rainy season from September to November. In August 2005, very heavy rains ( $278 \mathrm{~mm}$ of water in six days) flooded many parts of the city. Many potential breeding sites were created, and the An gambiae s.l. aggressiveness was high, with a peak of almost 200 bites per person per night in September. This abnormal situation in Dakar,

Table 3: Genotypic frequencies for Kdr loci of two samples of $A$. arabiensis collected in the French military camps of Bel air and Ouakam from May 2005 to May 2006.

\begin{tabular}{ccc}
\hline & Bel-air & Ouakam \\
\hline RR & II $(0,10)$ & $5(0,05)$ \\
RS & $4(0,04)$ & $9(0,09)$ \\
SS & $94(0,86)$ & $90(0,86)$ \\
Total & 109 & 104
\end{tabular}

due to an exceptional climatic event, could have led to an exceptional malaria transmission. However, the catch of infected Anopheles during the 2006 winter proved that malaria transmission is not exceptional and occurred each year during this period. These data agree with clinical data from a Senegalese military Hospital of Dakar (Hospital Principal), where most malaria cases occur between October and December.

Only specimens of An. arabiensis were infected. Anopheles arabiensis is the main member of the gambiae complex in Dakar and, according to its abundance and to the results of this study, is the main malaria vector. The presence of An. melas was detected in Dakar for the first time in the present study. Nevertheless, this vector was not found to be infected with P. falciparum. Until now, An. melas had been reported only in the mangrove swamps of the Delta's Saloum (south Senegal) and in the Senegal River delta (north Senegal) $[18,19]$. In addition, neither Anopheles pharoensis nor An. gambiae molecular form $\mathrm{M}$ caught in Dakar were infected with $P$. falciparum. The aggressiveness of An. arabiensis was higher in Bel-air than in Ouakam, but EIRs were very high in the two quarters. An. arabiensis is more endophagic in Ouakam. This behavior allows for an easier access to a human blood meal that may explain the similar EIRs observed for the two quarters.

The seasonal character of transmission allows us to calculate mean annual EIR for the two years of study. In Bel-air, the mean annual EIR fell from 9.5 in 2005 to 4 in 2006. In Ouakam, a similar mean annual EIR of 3 was estimated for 2005 and 2006. Our observations are consistent with the results of a meta-analysis of studies of malaria transmission in sub-Saharan Africa, which found a mean annual EIR of 7.1 in the city centers, with more than twothirds of the studies reporting EIRs < 4/year [20]. In 1996, the number of infective bites per person was estimated to 0.05/year for the central area of Dakar, i.e., one infective bite every 20 years [10]. This work was conducted on a very large area with 13 study sites but with only two catching points per site and human landing collections performed once every month. Ten years later, the risk of malaria transmission seemed to be 60 to 80 times higher. The peak of An. gambiae s.l. aggressiveness lasts for a little longer than one month (Figure 3). With a monthly rhythm of capture, the previous study could have missed this peak. Nevertheless, a modification of the entomological situation over ten years cannot be excluded. There is some evidence that anopheline species may be adapting to urban ecosystems. Adaptation of An. gambiae s.s. to urban aquatic habitats, such as water-filled domestic containers, has been observed in Accra, Ghana [21]. In addition, adaptations of the anopheline vectors to new breeding sites (tree holes, polluted water) are reported from many urban areas in Africa [22-24]. The impact of 
urbanization on the composition of the vector system and malaria transmission dynamics has been highlighted in many studies $[25,26]$. Urban farming provides ample aquatic habitats for mosquitoes, which are responsible for the persistence of anopheline populations in many African towns [27-29]. In Ouakam and Bel-air, as in other places in Dakar, market gardens are present with or without water wells (cement wells or traditional wells called "ceanes"). The urban area of Dakar contains more than 5,000 market-garden wells, which provide permanent sites for mosquito larvae, in particular An. Arabiensis [30]. The increase of the An. arabiensis population size during the 2005 winter is an argument to highlight the major role of temporary pools in malaria transmission in Dakar. Further specific study is necessary to understand the impact wells and urban farming on anopheline density and malaria transmission.

This situation questions the origins of these anopheline populations. Are there autochthonous populations from Dakar growing during the rainy season, or are they coming in from other areas of Senegal? Populations of An. arabiensis in West Africa are considered to be continuous throughout the year, with many individuals surviving through the dry season, perhaps in a physiologically altered state rather than through extinction or a severe bottleneck during the dry season, followed by re-colonization by a few individual survivors or immigrants in the subsequent rainy season [31]. In Barkedji, Senegal, Simard $e t$ al did not detect any difference in measures of genetic diversity and linkage disequilibrium between the dry and rainy seasons [32]. They concluded that, despite extreme minima in local density, malaria transmission in this area was due to autochthonous population of An. arabiensis. They also found a low differentiation between two populations, which were $250 \mathrm{Km}$ apart, suggesting extensive gene flow across this distance. These results suggest that $A n$. arabiensis maintains a large permanent deme over a large area. The situation in Dakar seems similar to that in Barkedji: a long dry season where no An. arabiensis (or only a few) are caught [33]. Further genetic studies will be necessary to confirm the hypothesis that malaria transmission is due to an autochthonous An. arabiensis population, and to assess the gene flow between the urban and rural populations of Senegalese An. arabiensis.

Pyrethroids are the main insecticide used in malaria vector control, including indoor residual spraying and impregnated materials (bednets, curtains, plastic sheeting). Pyrethroids have the advantage of acting very rapidly as insecticides, with both knockdown and lethal effects at dosages under the threshold of mammalian toxicity [34]. Since 1970s, pyrethroids have been extensively used in urban areas and for agricultural purpose in rural areas. Detected in the 1990s, knock-down resistance (Kdr) to pyrethroids and DDT of An. gambiae s.l is an increasing problem. Two mutations at the same locus in the voltagegated sodium channel are known to confer knock-down resistance to a wide range of pyrethroids and DDT [3537]. These mutations were previously described in west and east Africa ( $K d r-w$ and $K d r-e)$ in An. gambiae s.s. as well in An. arabiensis [38-41]. There are few studies of An. arabiensis insecticide susceptibility in the area of Dakar. In 1987 , bioassays were conducted in two places in the suburbs of Pikine and of Thiaroye [42], where in vivo resistance to DDT was observed. The agricultural use of DDT in market gardens was incriminated. In 1999, a normal susceptibility of An. arabiensis was found in Dakar [43]. Our data show a $K d r-w$ frequency of 0.12 in Bel-air and 0.09 in Ouakam. The populations were not at Hardy-Weinberg equilibrium for $K d r$ in either site $(\mathrm{P}<0.0001)$. This disequilibrium could be due to local selection pressure by the agricultural use of pyrethroids in market gardens.

The Kdr mutation has been shown to be closely associated with DDT and pyrethroid resistance in several An. gambiae populations (particularly the molecular S form) [35-37]. However, the role of $K d r$ in conferring resistance in $A n$. arabiensis remains unclear $[44,45]$ As a result, insecticide susceptibility tests should be carried out to assess physiological resistance levels in An. arabiensis in Dakar. However, this is the first report of the Kdr-w mutation in $A n$. arabiensis in Dakar. Resistance to carbamate and organophosphate insecticides is also widespread in West Africa. The presence of an insensitive acetylcholinesterase in populations of An. gambiae s.s. of both forms was revealed by biochemical assays. The ACE-1-R mutation has also been detected in the two molecular forms of An. gambiae s.s in many West African countries $[17,46]$. This mutation has not been detected in An. arabiensis at present. Our results are consistent with these data.

In terms of effective vector control at the military camps and in town, choice of insecticide should depend on the results of susceptibility tests on An. arabiensis.

Malaria prevalence is very low in Dakar and its urban periphery $[7,8,10]$. Nevertheless, cerebral malaria is the first etiology of neuromeningeal diseases in Dakar [47]. Extensive genetic diversity was observed in $P$. falciparum isolates collected in Dakar [48-50]. Significant linkage disequilibrium was observed with microsatellite loci in urban parasites. Two non-exclusive hypothesis could explain the situation in Dakar: (i) a global non-panmictic structure of Dakar malaria population due to a high predominance of selfing; (ii) a structuration in subpopulations of several malaria foci in Dakar. The entomological findings of the present study are consistent with seasonal transmission leading to an increase of cases in the October end of the rainy season. There is a concern about the ori- 
gin of Plasmodium falciparum infections observed in Dakar during the rainy season. Are they due to autochthonous parasites transmitted during the winter or to parasites imported from the suburbs by commuters, as suggested by Vercruysse? [6] In Senegalese people employed by the French army, the first malaria cases are diagnosed in commuters at the beginning of the rainy season, and cases in residents occur later in the season. The movement of populations from the suburbs or rural areas to Dakar must be considered to understand malaria epidemiology in Dakar $[51,52]$.

Urban malaria is considered to be an emerging problem in Africa. In 2003, 39\% of Africa's people lived in urban settings; by 2030, 54\% of Africans are expected to do so [53]. With the increase of people living in urban dwellings, it's important to develop and validate new approaches for rapid appraisal of malaria risk. The rapid urban malaria appraisal (RUMA) methodology has been develop to provide a cost effective tool to conduct assessment of the malaria situation in urban sub-Saharan Africa and to improve the understanding of urban malaria [54]. The only entomological point required is in this evaluation is the mapping of breeding sites. Considered very time-consuming, this task has been done only in Ouagadougou [27].

The results of this study confirm that the vector complex situation in African towns is always changing, with the description of An melas and An gambiae s.s. in Dakar. Entomological studies are long, difficult and require time and special expertise but they are indispensable to understand the dynamics of malaria transmission in urban settlements and to monitor the increase of the insecticide resistance in urban mosquitoes. The study showed a difference in host finding behaviour between the two quarters: $A n$. arabiensis are more endophagic in Ouakam than in Bel air. This difference of behaviour has an impact on the malaria transmission level. With a lower biting activity during the transmission season, the Annual EIR in Ouakam remains as high than in Bel air. Indoor vector control measures will probably not have the same impact in the two quarters. The misuse of impregnated bed nets during this period is probably riskier in Ouakam.

Malaria is transmitted in Dakar. This seasonal transmission occurs only during the two last months of the rainy season. The transmission level could be very high. Further studies have to be conducted in other parts of Dakar to assess the risk of transmission, to understand the role of permanent and temporary pools, the impact of urban farming and to discover the origin of the Dakar anopheline populations.

\section{Competing interests}

The authors declare that they have no competing interests.

\section{Authors' contributions}

FP was responsible for the study design, supervision of data collection, analysis, interpretation and production of the final manuscript and revisions. GT contributed to the supervision of data collection, the data analysis, interpretation and production of final manuscript. BP contributed to the supervision of data collection, to the data analysis, interpretation and production of final manuscript. LG contributed to the supervision of data collection, to the data analysis, interpretation and production of final manuscript. VM contributed to the data analysis and to the preparation of the final manuscript. FJ contributed to the supervision of data collection, to the data analysis. KP contributed to the supervision of data collection, to the data analysis. FB contributed to the supervision of data collection, to the data analysis. JFT was contributed to overall scientific management, analysis, interpretation and preparation of the final manuscript and revisions. CR was contributed to overall scientific management, analysis, interpretation and preparation of the final manuscript and revisions. CS was responsible for overall scientific management, analysis, interpretation and preparation of the final manuscript and revisions. All authors read and approved the final manuscript.

\section{Acknowledgements}

We acknowledge Didier Fontenille for his advice. We thank the collector's team for commitment in the fieldwork as well as the French military authorities in Dakar. We also acknowledge the Senegalese National

Weather Agency for its help. This investigation received financial support from the Medical Services of the French Ministry of Defence.

\section{References}

I. Armengaud M, Louvain M, Diop Mar I: Etude portant sur 448 cas de paludisme chez l'Africain de la région dakaroise. Bull Soc Med Afr Noire Lang fr 1962, 2:167.

2. $\mathrm{Ba} H$, Maffre $\mathrm{E}$ : Le paludisme dans la région du cap vert au cours de I'hivernage 1966. Médecine d'Afrique Noire 1967, I 4:3 I5.

3. Kane $Y$, Kane $O$, Maffre $E$ : Contribution à l'étude de l'endémie palustre dans la ville de Dakar. Bull Soc Med Afr Noire Lang fr 1968, I: I89-194.

4. Michel R: La lutte antipaludique au Sénégal. Espoirs, déceptions et orientations nouvelles. Gazette médicale de France 1967, 9:17|3-172I.

5. Rey M, Camerlynck P, Diop Mar L, Lafaix CH, Sow A: Le paludisme dans I'agglomération dakaroise. Bull Soc med Afr noire Langue fr 1968, 13:353-365.

6. Vercruysse J, Jancloes M, Velden L Van de: Epidemiology of seasonal falciparum malaria in an urban area of Senegal. Bull World Health Organ 1983, 61:821-831.

7. Trape JF, Lefebvre-Zante E, Legros F, Ndiaye G, Bouganali H, Druilhe $P$, Salem G: Vector density gradients and the epidemiology of urban malaria in Dakar, Senegal. Am J Trop Med Hyg 1992, 47:181-189.

8. Diallo S, Ndir O, Faye O, Diop BM, Dieng Y, Bah IB, Dieng T, Gaye $O$, Konate $L$ : Malaria in the southern sanitary district of Dakar (Senegal). I. Parasitemia and malarial attacks. Bull Soc Pathol Exot 1998, $91: 208-213$.

9. Diallo S, Konate L, Faye O, Ndir O, Faye M, Gueye A, Diouf M: Malaria in the southern sanitary district of Dakar (Senegal). 2. Entomological data. Bull Soc Pathol Exot 1998, 9 I:259-263. 
10. Diallo S, Konate L, Ndir O, Dieng T, Dieng Y, Bah IB, Faye O, Gaye $O$ : Malaria in the central health district of Dakar (Senegal). Entomological, parasitological and clinical data. Sante 2000, 10:221-229.

1I. Gillies MT, Coetzee M: A supplement to the anophelinae of Africa south of the Sahara (Afrotropical region) The South African Institut for Medical Research No. 55 Johannesburg, South Africa; 1987.

12. Hervy JP, Le Goff G, Geoffroy B, Herve JP, Manga L, Brunhes J: Logiciel d'identification et d'enseignement. Les anophèles de la région afrotropicale CD-ROM Ed. ORSTOM, Série Didactiques, ORSTOM/OCEAC; 1998.

13. Edwards FW: Mosquitoes of the Ethiopian Region. III- Culicine adults and pupae. London: British Museum (Natural History); 194I.

14. Burkot TR, Zavala F, Gwadz RW, Collins FH, Nussenzweig RS, Roberts DR: Identification of malaria infected mosquitoes by a two-site enzyme-linked immunosorbent assay. Am J Trop Med Hyg 1984, 33:227-23I.

15. Fanello C, Santolamazza F, Della Torre A: Simultaneous identification of species and molecular forms of the Anopheles gambiae complex by PCR-RFLP. Med Vet Entomol 2002, 16:46|-464.

16. Lynd A, Ranson H, McCall PJ, Randle NP, Black WC 4th, Walker ED, Donnelly MJ: A simplified high-throughput method for pyrethroid knock-down resistance (kdr) detection in Anopheles gambiae. Malar J 2005, 4: 16

17. Weill M, Malcolm C, Chandre F, Mogensen K, Berthomieu A, Marquine $M$, Raymond $M$ : The unique mutation in ace-I giving high insecticide resistance is easily detectable in mosquito vectors. Insect Mol Biol 2004, 3: I-7.

18. Diop A, Molez JF, Konaté L, Fontenille D, Gaye O, Diouf M, Diagne M, Faye O: Role of Anopheles melas Theobald (1903) on malaria transmission in a mangrove swamp in Saloum (Senegal). Parasite 2002, 9:239-246.

19. Petrarca V, Vercruysse J, Coluzzi M: Observations on the Anopheles gambiae complex in the Senegal River Basin, West Africa. Med Vet Entomol 1987, I:303-3/2.

20. Robert V, Macintyre K, Keating J, Trape JF, Duchemin JB, Warren M, Beier JC: Malaria transmission in urban subsaharian Africa. Am J Trop Med Hyg 2003, 68:169-176.

21. Chinery WA: Effects of ecological changes on the malaria vectors Anopheles funestus and the Anopheles gambiae complex of mosquitoes in Accra, Ghana. J Trop Med Hyg 1984, 87:75-8I.

22. Awolola TS, Oduola AO, Obansa JB, Chukwurar NJ, Unyimadu JP: Anopheles gambiae s.s. breeding in polluted water bodies in urban Lagos, southwestern Nigeria. J Vector Borne Dis 2007 44:24I-244.

23. Mireji PO, Keating J, Hassanali A, Mbogo CM, Nyambaka $\mathrm{H}$, Kahindi S, Beier JC: Heavy metals in mosquito larval habitats in urban Kisumu and Malindi, Kenya, and their impact. Ecotoxicol Environ Saf 2008, 70:147-153.

24. Omlin FX, Carlson JC, Ogbunugafor CB, Hassanali A: Anopheles gambiae exploits the treehole ecosystem in Western Kenya: A New Urban Malaria Risk? Am J Trop Med Hyg 2007, 77(Suppl 6):264-269.

25. Khaemba BM, Mutant A, Bett MK: Studies of anopheline mosquitoes transmitting malaria in a newly developed high-land urban area: a case study of Moi University and its environs. East Afr Med 1994, 71:159-164.

26. Antonio-kondjio C, Simard F, Awono-Ambene P, Ngassam P, Toto $J C$, Tchuinkam T, Fontenille D: Malaria vectors and urbanization in the equatorial forest region of south Cameroon. Trans $R$ Soc Trop Med Hyg 2005, 99:347-354.

27. Wang SJ, Lengeler C, Smith TA, Vounatsou P, Diadie DA, Pritroipa $X$, Conelbo N, Kientga M, Tanner M: Rapid urban malaria appraisa (RUMA) I: Epidemiology of urban malaria in Ouagadougou. Malar J 2005, 4:43-59.

28. Girod R, Orlandi-Pradines E, Rogier C, Pages F: Malaria Transmission and Insecticide Resistance of Anopheles gambiae (Diptera: Culicidae) in the French Military Camp of Port-Bouët, Abidjan (Côte d'Ivoire): Implications for Vector Control. Med Entomol 2006, 43:1082-1087.

29. Matthys B, Vounatsou P, Raso G, tscannen AB, Becket EG, Gosoniu L, Cisse G, Tanner M, N'goran EK, Utzinger J: Urban farming and malaria risk factors in a medium-sized town in Côte d'Ivoire. Am J Trop Med Hyg 2006, 75: I223-I23I.
30. Robert V, Awono-Ambene HP, Thioulouse J: Ecology of larval mosquito, with special reference to Anopheles arabiensis (Diptera: Culicidae) in market-garden wells in the urban area of Dakar, Senegal. J Med Entomol 1998, 35:948-955.

3I. Taylor CE, Toure YT, Coluzzi M, Petrarca V: Effective population size and persistence of Anopheles arabiensis during the dry season in West Africa. Med Vet Entomol 1993, 7:35I-357.

32. Simard F, Lehmann T, Lemasson JJ, Diatta M, Fontenille D: Persistence of Anopheles arabiensis during the severe dry season conditions in Senegal: an indirect approach using microsatellite loci. Insect Mol Biol 2000, 9:467-79.

33. Lemasson J], Fontenille D, Lochouarn L, Dia I, Simard F, Ba K, Diop A Diatta M, Molez JF: Comparison of behavior and vector efficiency of Anopheles gambiae and An. Arabiensis (Diptera: Culicidae) in Barkedji, a Sahelian area of Senegal. J Med Entomol 1997, 34:396-403.

34. Chavasse DC, Yap HH: Chemical methods for the control of vectors and pests of public health importance WHO/CTD/WHOPES/97.2. World Health Organization, Geneva.

35. Martinez-Torres D, Chandre F, Williamson MS, Darriet F, Bergé JB, Devonshire AL, Guillet P, Pasteur N, Pauron D: Molecular characterization of pyrethroid knockdown resistance (kdr) in the major malaria vector Anopheles gambiae s.s. Insect Mol Biol 1998, 7:179-184.

36. Brooke BD, Hunt RH, Koekemoer LL, Dossou-Yovo J, Coetzee M: Evaluation of a polymerase chain reaction assay for detection of pyrethroid insecticide resistance in the malaria vector species of the Anopheles gambiae complex. J Am Mosq Control Assoc 1999, 15:565-568.

37. Chandre F, Darriet F, Duchon S, Finot L, Manguin S, Carnevale $P$, Guillet P: Modifications of pyrethroid effects associated with kdr mutation in Anopheles gambiae. Med Vet Entomol 2000, I4:8|-88.

38. Ranson H, Jensen B, Vulule J, Wang X, Hemingway J, Collins F: Identification of a point mutation in the voltage-gated sodium channel gene of Kenyan Anopheles gambiae associated with resistance to DDT and pyrethroids. Insect Mol Biol 2000, 9:49|-497.

39. Diabate A, Baldet T, Chandre F, Dabire KR, Simard F, Ouedraogo JB, Guillet $P$, Hougard JM: First report of kdr mutation in Anopheles arabiensis from Burkina Faso, West Africa. J Am Mosq Control Assoc 2004, 20:195-196.

40. Verhaeghen K, Van Bortel W, Roelants P, Backeljau T, Coosemans M: Detection of the East and West African kdr mutation in Anopheles gambiae and Anopheles arabiensis from Uganda using a new assay based on FRET/Melt Curve analysis. Malar J 2006, 5: 16 .

4I. Hemingway J, Hawkes NJ, McCarroll L, Ranson H: The molecular basis of insecticide resistance in mosquitoes. Insect Mol Biol 2004, 34:653-665.

42. Faye O, Gaye O, Diallo S: Evaluation de la sensibilité d'An. gambiae s.l. au fenitrothion et au DDT au Sénégal. Dakar Médical 1991, 36:170-177.

43. Chandre F, Darriet F, Manga L, Akogbeto M, Faye O, Mouchet J, Guillet $P$ : Status of pyrethroid resistance in Anopheles gambiae sensu lato. Bull World Health Organ 1999, 77:230-234.

44. Matambo TS, Brooke BD, Koekemoer LL, Hunt RH, Coetzee M: Insecticide resistance in Anopheles arabiensis and association with the kdr mutation. Med Vet Entomol 2007, 21:97-102.

45. Brooke BD: Kdr: can a single mutation produce an entire insecticide resistance phenotype? Trans $R$ Soc Trop Med Hyg 2008, 102:524-525.

46. Djogbénou L, Dabiré R, Diabaté A, Kengne $P$, Akogbéto $M$, Hougard JM, Chandre $F$ : Identification and geographic distribution of the ACE-IR mutation in the malaria vector Anopheles gambiae in south-western Burkina Faso, West Africa. Am J Trop Med Hyg 2008, 78:298-302.

47. Soumaré M, Seydi M, Ndour CT, Fall N, Dieng Y, Sow AI, Diop BM: Epidemiological, clinical, etiological features of neuromeningeal diseases at the Fann Hospital Infectious Diseases Clinic, Dakar (Senegal). Med Mal Infect 2005, 35:383-389.

48. Robert F, Ntoumi F, Angel G, Candito D, Rogier C, Fandeur T, Sarthou JL, Mercereau-Puijalon O: Extensive genetic diversity of Plasmodium falciparum isolates collected from patients with severe malaria in Dakar, Senegal. Trans $R$ Soc Trop Med Hyg 1996, 90:704-7|I. 
49. Leclerc MC, Durand P, de Meeus T, Robert V, Renaus F: Genetic diversity and population structure of Plasmodium falciparum isolates from Dakar, Senegal, investigated from microsatellite and antigen determinant loci. Microb Infect 2002, 4:685-692.

50. Henry M, Diallo I, Bordes J, Ka S, Pradines B, Diatta B, M'Baye PS, Sane M, Thiam M, Gueye PM, Wade B, Touze JE, Debonne JM, Rogier C, Fusai T: Urban malaria in Dakar, Senegal: chemosusceptibility and genetic diversity of Plasmodium falciparum isolates. Am J Trop Med Hyg 2006, 75: |46-I5I.

51. Prothero RM: Disease and mobility: a neglected factor in epidemiology. Int J Epidemiol 1977, 6:259-267.

52. Bogreau H, Renaud F, Bouchiba H, Durand P, Assi SB, Henry MC Garnotel E, Pradines B, Fusai T, Wade B, Adehossi E, Parola P, Ali Kamil M, puijalon O, Rogier C: Genetic diversity and structure of African Plasmodium falciparum populations in urban and rural areas. Am J Trop Med Hyg 2006, 74:953-959.

53. Keiser J, Utzinger J, Caldas de Castro M, Smith TA, Tanner M, Singer $\mathrm{BH}$ : Urbanization in sub-Saharan Africa and implications for malaria control. Am J Trop Med Hyg 2004, 7 I (suppl 2): I I8-I 27.

54. Wang SJ, Lengeler C, Smith TA, Vounatsou P, Cisse G, Diallo DA, Akogbeto M, Matsiwa D, Teklehaimanot A, Tanner M: Rapid urban malaria appraisal (RUMA) in sub-Saharan Africa. Malar J 2005, 4:40.

Publish with Bio Med Central and every scientist can read your work free of charge

"BioMed Central will be the most significant development for disseminating the results of biomedical research in our lifetime. "

Sir Paul Nurse, Cancer Research UK

Your research papers will be:

- available free of charge to the entire biomedical community

- peer reviewed and published immediately upon acceptance

- cited in PubMed and archived on PubMed Central

- yours - you keep the copyright

Submit your manuscript here:

http://www.biomedcentral.com/info/publishing_adv.asp
BiolMedcentral 